Discussion Paper No. 07-013

\title{
The Influence of Strategic Patenting on Companies' Patent Portfolios
}

Knut Blind, Katrin Cremers, and Elisabeth Mueller

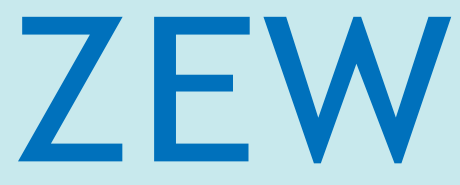

Zentrum für Europäische Wirtschaftsforschung $\mathrm{GmbH}$

Centre for European

Economic Research 
Discussion Paper No. 07-013

\section{The Influence of Strategic Patenting on Companies' Patent Portfolios}

Knut Blind, Katrin Cremers, and Elisabeth Mueller

Download this ZEW Discussion Paper from our ftp server:

ftp://ftp.zew.de/pub/zew-docs/dp/dp07013.pdf

Die Discussion Papers dienen einer möglichst schnellen Verbreitung von neueren Forschungsarbeiten des ZEW. Die Beiträge liegen in alleiniger Verantwortung der Autoren und stellen nicht notwendigerweise die Meinung des ZEW dar.

Discussion Papers are intended to make results of ZEW research promptly available to other economists in order to encourage discussion and suggestions for revisions. The authors are solely responsible for the contents which do not necessarily represent the opinion of the ZEW. 


\section{Non-technical Summary}

The role of patents changed fundamentally in the 1990s. The number of patent applications increased notably faster than companies' $R \& D$ expenditures, even though companies attributed a decreased role to patents in protecting innovations. Patents gained a strategic importance that exceeded their traditional role of appropriating direct returns from R\&D. Patenting has been motivated by the desire to block competitors in their research activities (blocking motive). In addition, patents have become important assets in R\&D collaborations, to generate licensing revenues or to enter cross-licensing agreements (exchange motive). It has been assumed that, alongside the traditional protection motive, these additional strategic motives have an influence on the characteristics of companies' patent portfolios. However, no insights into this relationship have been available until now.

This paper analyses whether strategic motives for patenting influence the characteristics of companies' patent portfolios. As first characteristic we use the average number of citations that the patents in a portfolio receive. The number of citations can be interpreted as a value indicator. The more citations a patent receives from later patent applications the higher its value. The second characteristic is the share of patents in a portfolio that receive an opposition. Within nine months after the grant of a patent by the European Patent Office (EPO), any third party can file an opposition against it. In an opposition proceeding the validity of a patent is checked.

The investigation is based on survey data from more than 400 German companies that was combined with patent information from the EPO. There is evidence that the patenting strategies of companies help to explain the characteristics of their patent portfolios. First, companies that use patents in their traditional function of protecting innovations from imitation receive, on average, a higher number of citations for their patents than companies that emphasise the more strategic motives of blocking and exchange. Interpreting the number of citations as an indicator of value, we find that strategic motives lead to patents of lower value. This finding is of great importance to policy makers who are concerned that an increasing number of patents of low value may lead to patent thickets that could hinder innovation. Second, we find that the motive of offensive blocking but not of defensive blocking is related to a higher incidence of oppositions, whereas companies emphasising the exchange motive receive fewer oppositions to their patents. Obviously, companies which collaborate in R\&D or cross-license patents on a regular basis may try to avoid patent conflicts or may prefer to resolve such conflicts informally. 


\title{
The Influence of Strategic Patenting on Companies' Patent Portfolios
}

\author{
Knut Blind*, Katrin Cremers**, Elisabeth Mueller**
}

January 9, 2007

\begin{abstract}
This paper analyses whether strategic motives for patenting influence the characteristics of companies' patent portfolios. We use the number of citations and oppositions to represent these characteristics. The investigation is based on survey and patent data from German companies. We find clear evidence that the companies' patenting strategies explain the characteristics of their patent portfolios. First, companies using patents to protect their technological knowledge base receive a higher number of citations for their patents. Second, the motive of offensive - but not of defensive - blocking is related to a higher incidence of oppositions, whereas companies using patents as bartering chips in collaborations receive fewer oppositions to their patents.
\end{abstract}

JEL: O 34, O 32

Keywords: strategic patenting, patent portfolio characteristics

* Berlin University of Technology, Chair of Innovation Economics, VWS 2 and Fraunhofer Institute for Systems and Innovation Research, Berlin Office, Müller-Breslau-Straße, 10623 Berlin, Germany, Knut.Blind@TU-Berlin.de

** Center for European Economic Research (ZEW), Department of Industrial Economics and International Management, L7,1,68161 Mannheim, Germany, cremers@zew.de and mueller@zew.de

We would like to thank Dietmar Harhoff and Konrad Stahl for helpful discussions. We thank Martina Schilling und Tobias Veith for assistance with the set-up of the data set. We would like to thank participants of the SFB/TR Workshop 2006 in Wuerzburg, the Schumpeter Conference 2006 in Nice, the Annual Meeting of EARIE 2006 in Amsterdam, the Annual Conference of the Verein fuer Socialpolitik in Bayreuth, the Annual Meeting of EPIP 2006 in Munich, the SFB/TR Seminar in Mannheim and the MSI Faculty Seminar in Leuven for providing helpful comments. Katrin Cremers and Elisabeth Mueller gratefully acknowledge financial support from the German Science Foundation (DFG) under grant SFB/TR 15-04. 


\section{Introduction}

One phenomenon of the 1990s which was observed in several European countries, but also the USA and Japan, was a strong increase in patent applications. At the same time, private expenditure on $R \& D$ grew only modestly. Consequently, the patent intensity, defined as patent applications per unit of $R \& D$ expenditure, increased significantly (Blind et al. 2004). In this context, several authors (Jaffe, Lerner 2004; Shapiro 2003) highlight the innovation-hindering effect of patents. Several explanations for this phenomenon are provided in the literature, although none can claim to be able to explain the whole story (Jaffe 1999). First, it is argued that the R\&D process became more efficient or more differentiated by a further division of labour, leading to a higher number of inventions and therefore of patents per unit of R\&D expenditure (Janz et al. 2001). Second, patent applications have been extended to promising and expanding new fields of technology (Kortum, Lerner 1999), like biotechnology (e.g. Thumm 2003) and software (e.g. Blind et al. 2005). Third, patent strategies have changed and became more complex and comprehensive, leading to an expansion of patent applications (Blind et al. 2004).

The first explanation does not provide a source for concern and the second involves external technological or political forces, which cannot be dealt with in one single paper. Accordingly, our analysis focuses on the third. A number of previous studies present structures and the extent of strategic patenting (Arundel et al. 1995; Cohen et al. 2002; Schalk et al. 1999). They argue that the patent system, the original purpose of which is the temporary protection of a company's the technological knowledge base, is used by companies for various further so called "strategic" motives. For example, patents are also an instrument for securing one’s own future technological space against competitors or for restricting their future technological opportunities. In recent years, patents have become important assets in collaborations, to generate licensing revenues or to get better access to the capital market, especially for start-up companies. Finally, patents can also be used by companies' management as a performance indicator and even linked to reward schemes for researchers.

Parallel to the emerging literature on strategic patenting, numerous authors have concentrated on the analysis of indicators to determine the economic value of patents. In bibliographic analyses, the number of citations is accepted as a reliable value indicator. It can be successfully transferred to patents. ${ }^{1}$ Furthermore, the incidence of patent oppositions is a good signal that a patent is valuable. Several studies have looked into both

1 See Lanjouw and Schankerman (2004) for a comprehensive overview. 
the interrelationship of the various value indicators and their explanatory power for the monetary value of patents (Harhoff et al. 2003; Harhoff, Reitzig 2004; Lanjouw, Schankerman 2004; Traijtenberg 1990).

In our paper, we try for the first time to bridge the gap between the research on strategic patenting and investigations into companies' patent portfolios. Additionally, we focus explicitly on the characteristics of a company's portfolio and not on single patents. We extend the systematic analysis of factors explaining the motives of strategic patenting in Germany by Blind et al. (2006). Our aim is to investigate the relationship between strategic patenting and the characteristics of companies' patent portfolios, measured by various value indicators. This paper is based on survey data collected by Blind et al. (2003) for a sample of almost 500 patenting companies in Germany. It presents insights into the influence of strategic patenting on the characteristics of companies' patent portfolios, like the number of citations per patent or the likelihood of oppositions.

Using this comprehensive database, we perform numerous multivariate regressions leading to the following insights. There is strong evidence that the motive structure affects the results of the patent examination process, i.e. references to other patent claims, or the opposition behaviour of other applicants. We find that the more intensively companies use patents to achieve the protection objective, the higher is the average number of citations their patent portfolio receives. Conversely, in cases where strategic motives, such as blocking and exchange, dominate, portfolios receive less citations and are hence of lower value on average. Furthermore, our results show that the incidence of opposition against a company's portfolio is higher when the company assesses the offensive blocking motive as important. This implies that competitors also perceive this motivation and are more likely to react with disputes against those companies. Simultaneously, companies that regard their patent motives mostly as driven by cooperation and exchange goals are faced with proportionally fewer oppositions to patents in their portfolios than companies using patents mainly for protective reasons. These insights allow us also to derive recommendations for future patent policy. Markets for technology are obviously rather efficient in the sense of information efficiency, since companies using patents as bartering chips possess patent portfolios of similar characteristics. The phenomenon of frequent oppositions and rather limited citations in a company's patent portfolio is an indicator for the implementation of an offensive blocking strategy. Such a strategy could lead to "patent thickets", generating higher costs for innovating competitors. Whether policy makers should react to this anticompetitive behaviour depends on the extent of these thickets and their implications for further inventions.

The remainder of the paper is structured as follows. In Chapter 2 we discuss several patenting motives. In Chapter 3, we present the most relevant indicators for measuring the value of patents. In Chapter 4 we develop a set of hypotheses for the empirical in- 
vestigation of the relationship between the different strategic motives for patenting and the characteristics of patent portfolios. Chapter 5 presents the merged database we use for our empirical analysis and some descriptive statistics. In Section 6, the results of a series of regressions are displayed and used to validate or revise the hypotheses developed in Chapter 4. The paper concludes with a summary of results and challenges for future research.

\section{Motives to Patent}

Different approaches can be taken to classify strategic motives to patent. The basic function of a patent as originally intended by the architects of the patent system is to provide an effective instrument to prevent imitation by competitors, in order to secure the appropriability of the earnings from innovative technologies. If this is achieved, patents should also increase the incentive to invest in innovative activities. However, the existence of the patent system also creates opportunities to use these patents for different purposes. Therefore, the motives for patenting vary among patentees. There is no agreed definition of strategic patenting, although most experts include the use of patents to block competitors and the use of patents in negotiations with other companies.

Arundel and Patel (2003) divide these strategic (in contrast to traditional) reasons into defensive and offensive strategies. A firm will patent defensively in order to stop other firms from patenting one of its inventions and suing it for infringement, even though the firm does not need a patent on the invention to earn a return on its investments in innovation. ${ }^{2}$ These approaches refer mainly back to the function of patents to block other market participants from using technologies which are protected by patents but not necessarily used in business. This strategy can be intended from the beginning of the patent application process or can emerge from the fact that certain patents are not worth exploiting but only used to build a protected area around other patents of the company. Firms patent offensively to prevent or block other firms from patenting inventions that are similar, but not identical, to the invention that they plan to commercialise. In this case, the firm builds a much broader patent wall - compared to defensive patenting around its invention. This prevents other firms from commercialising competing prod-

2 The returns derived from non-patent appropriation methods such as secrecy or lead-time advantages, which are also defensive in character, have consistently been shown in innovation surveys to be more valuable to firms than patents (Arundel et al. 1995; Cohen et al. 2000; Granstrand 1999). For analyses of the relationship between patenting and secrecy see for example Arundel (2001) and Hussinger (2006). 
ucts, even though the firm does not intend to market or license these other products itself.

Furthermore, firms may choose to patent defensively in order to have something to trade with other firms. In some sectors, such as ICT, the use of patents in negotiations with other firms for technology access is probably one of the most important motives for patenting (Hall, Ziedonis 2001). This trading or cooperation argument is strengthened by Noel and Schankerman (2006) who found that a large patent portfolio enhances the bargaining power of a company. Negotiations about mergers, license contracts, or research co-operations depend mainly on how the partners evaluate the research efforts and results of their partners which is mainly measured in the number of patents in the companies' portfolio.

In the empirical literature, Blind et al. (2006) are able to divide the various motives for patenting into the traditional protection motive, the blocking motive, the reputation motive, the exchange motive, and the motive to use patents as incentives and as performance indicators for R\&D departments and employees. This distinction is based on a factor analysis, which condenses the complex multiplicity of motives in a meaningful manner. The groups generated by the factor analysis correspond very well to the motive clusters discussed in the literature.

\section{Patent Portfolio Characteristics}

Patents are heterogeneous in their value and function for their owners and supply different levels of additional profit to companies through the original protection function and strategic functions (Somaya 2003). The value a single patent has for its patentee is not observable. Even the absolute value of patent portfolios or patent stocks is hard to identify from survey data (Harhoff et al. 2003). In this section, we present the most reliable value indicators which can be used to describe the characteristics of a company's patent portfolio. We use the concept of the private value of the patented invention for the company. At this point we do not follow the general, long-lasting and still open discussion of the value of the patent rights as such compared to no patent at all. Besides the private value concept there is also a social value. However, we do not consider social value in our analysis.

At the European Patent Office (EPO) the examiner makes the ultimate decision on what patents will be included as references (backward citations) to the prior art related to the invention. The patent applicant may suggest patents which should be included as references. The references to earlier patents in the German and European patent system mark the boundaries of patentability and the basis the invention builds on. They are used to 
substantiate the patentability for which novelty and inventive activity are necessary. This function of citations implies that the number of citations received (forward citations) play a similar role to that of references in scientific publications as an indicator for the importance of the patent. Traijtenberg (1990) strongly supports this argument and Harhoff et al. (2003) provide broader evidence of the correlation between patent value and citations received in subsequent patent applications. However, one has to mention that citations can point to further technological development and a possible depreciation of the invention.

In addition to the number of citations, the incidence of an opposition is also a positive value indicator. Opposition is the first dispute about the validity of a granted patent. Any third party can file an opposition within nine months after a patent has been granted when there are reasons such as doubts as to novelty, doubts over a sufficient inventive step or when there might be pre-granting use of the invention prior to the patent application. The procedure is relatively cheap compared to a litigation procedure. However, there is no direct communication between the patentee and the opposer. This is different to a litigation procedure before a civil court. The rationale behind opposition is that the expected value of the protected invention is so high that it is worthwhile for competitors to oppose the patent in order to prevent or restrict the patentee's intellectual property right. Expected innovation rents for patents which withstood opposition procedures either amended or unchanged are proved to be higher than for non-opposed patents (Harhoff et al. 2006). This finding is strengthened by the analysis by Harhoff and Reitzig (2004), which shows that opposed EPO patents in biotechnology and pharmaceuticals are generally more valuable than those which were not opposed, based on measurements using several value indicators. On the one hand, a higher expected value of a patent attracts more interest from those who would wish to exploit that value. On the other hand, a patent which has faced and survived opposition becomes more valuable because survival indicates a stronger patent right. The fact that a patentee faces an opposition is a signal from potential or actual competitors. It reveals that the invention has been recognized to be relevant for other actors in the market and that they take the patent seriously. The result of those oppositions can be a rejection of the opposition or an amendment of the patent, both of which are considered to improve the quality of the patent. Amendments in the sense of restrictions to the original claims are also regarded as a quality check (Graham et al. 2003).

In the literature there are further indicators proved to be correlated with the value of the patent. In addition to the citation and opposition measure used in our empirical analysis, for completeness, the following four indicators have to be mentioned: references, family size (Putnam 1996), number of claims and routes of patent protection. 


\section{Hypotheses}

We focus on three main clusters of patenting motives and relate these to the selected indicators for the value of companies' patent portfolios: the original protection motive, the blocking motive and the exchange motive. The blocking motive is further divided into defensive and offensive blocking. Due to the special research questions of our analysis this structure is different from that used by Blind et al. (2006). The exchange motive is defined in a narrower sense by just focusing the use of patents for crosslicensing, for earning licensing revenues and to improve the company's own position in co-operations with other companies.

In order to analyse the influence of the various motives to patent on the value of the patented innovation we explain the average number of citations per patent in companies' patent portfolios by the expressed priorities of the companies' patenting motives. If the protection of the technological knowledge base via patenting is very important compared to the strategic motives to patent, we can assume that the protected know-how is rather valuable, which should be reflected in a higher number of citations of the patents. A similar argument is valid for the motive of securing market share via patenting. In contrast, the research and development activities of competitors can be blocked by patents of rather mediocre quality. Furthermore, blocking competitors is more successful if competitors are confronted with a higher number of patents claiming different aspects of the same technology. Consequently, the average quality of patents is likely to be lower if they are used to implement a blocking strategy.

In addition, the intention to block relates to future technological fields which may or may not be as valuable as anticipated. The uncertainty increases even further if a company applies for patents based on speculations about the possible future technological trajectories of its competitors, as in the case of offensive blocking. Defensive blocking is concentrated on the technological fields which are very close to the core technological area of the company and is therefore less speculative. Consequently, the quality of the patents should be closer to that of patents applied for in order to secure the actual knowledge base.

We are not convinced by the argument that patents applied for in order to block competitors receive a smaller number of citations, since competitors are completely deterred from the relevant technological field. Technologies have become more complex and numerous single components are necessary to construct a single final product or system. Consequently, patents on a specific type of technology for a single component do not reduce the attractiveness of patenting an alternative technology with similar functionalities, which may be the basis for a competing component. Such simultaneous innovation 
and patenting activities are very frequent in more complex industries, e.g. information technology (Varian et al. 2004).

Patents are not only used to block competitors in the market. They are also important instruments for collaborations with companies in both the vertical and horizontal market dimensions. Hall and Ziedonis (2001) show that patents allow a further differentiation of the value chain by promoting the division of work in the semi-conductor industry between rather small companies developing the blueprints of new technologies and rather large manufacturers owning production capacities and distribution systems. Furthermore, patents are playing an increasing role for collaboration at the horizontal level, since the increasing complexity of products, e.g. in the information and telecommunication industry, requires the use of a variety of technologies, which even large multinationals cannot efficiently invent and develop. Several studies support the positive relationship between participation in R\&D co-operation and patenting activities (Peeters, van Pottelsberghe de la Potterie 2006) there is no information available about the value of the patent portfolios of companies involved in co-operations, licensing or crosslicensing. In general, companies have to signal that they possess a rather large patent portfolio in order to get access to important co-operations or cross-licensing arrangements. Therefore, similarly to the patent portfolios of companies using patents for blocking reasons this size incentive has negative implications for the value of the average patent. Furthermore, there is a potential information asymmetry between the patent owners and possible co-operation partners and licensees about the quality of the patented technology, which may be exploited by the former.

Different mechanisms work on markets with information asymmetries between the supply and the demand side. On the supply side signalling strategies could be used, i.e. publishing the names of other licensees or even the citations of their patents. For example, various agencies managing patent pools publish the names of the licensees. Regarding the demand side, companies that use patents extensively as assets in the exchange with other actors have to expect that their collaborators or contract partners will analyse in depth the quality of the patents they are interested in. Consequently, low-quality patent applications might be detected and generate a negative reputation for their owners, which might also be perceived by other possible collaboration partners. 3 If companies assume a tendency towards efficient technology markets with very low information asymmetries, then companies interested in collaborations are expected to produce patents of a quality, which are not different to those patents foreseen for the implementation in own products, but even of higher quality, which should be reflected in above 
average citation rates. However, if collaboration partners do not have the competencies to detect the quality of patent portfolios or if collaboration is rather short term and collaboration partners change often, then we might observe fewer citations of patents from the portfolios of those companies using patents as assets in exchange processes. In our arguments, we highlight the incentive to produce at first a large patent portfolio and treat the still existing information asymmetry or moral hazard problem as given but not decisive. This is in line with new insights of Noel and Schankerman (2006) who find that bargaining power is considerably enhanced by the pure stock of the patents, even though the discussion about the valuation of patents as bargaining chips is growing. Taking these arguments we derive the following hypothesis: 4

H1: The average value of patents in a company's portfolio, measured in terms of the average number of citations of the patent portfolio, will be

a) high, when the motive of protection is important in the company's patent strategy,

b) low, when the motive of blocking competitors' inventions is important in the company's patent strategy,

c) low, when the motive of exchange and collaboration is important in the company's patent strategy.

A further characteristic of a patent portfolio is the share of oppositions received by patents in the portfolio of a company. Regarding the motives for patenting we have outlined, companies using patents to protect their valuable technological know-how, should expect on the one hand that oppositions from competitors will be more likely, because the rather valuable asset will generate a disadvantage for the competitor. On the other hand, if their patents are of high quality and possible opponents are aware of it, then opposition makes no sense. This argument depends on the predictability of the opposition process, i.e. the opponents can predict the outcome of the opposition process ex ante based on the objective quality of the opposed patent.

4 The following hypotheses can also be derived based on the simple optimisation of the profit of a company's profit by using the patent quality as decision variable. In contrast to choosing the optimal patent quality for securing the technological know-how for the internal use, producing patents for blocking competitors is characterised by higher costs due to the distance to the own technological core competencies, which leads to a relatively lower patent quality. If companies apply for patents as assets in exchange relations, the information asymmetries in the markets for technological knowhow create incentives to produce patents of lower quality compared to the quality of patents to be used for internal use. 
Compared to companies using patents to protect their own technological knowledge base, companies using patents explicitly as an instrument to block competitors in their competition strategies will receive a more critical feedback from competitors. Since the technological space and future market opportunities of the competitors will be deprived by these kinds of patents, they have a higher incentive to invest in opposing these kinds of applications. Furthermore, the chance of a successful opposition is higher due to the expectation that a blocking company has more low quality patents in its portfolio, for which the probability of opposition is higher. Consequently, we should expect a higher likelihood of opposition for the whole portfolio.

The motivation to use patents as assets in exchange processes, i.e. to generate licensing revenues, to use them in cross-licensing or for improving the position in co-operations, is based on a fairly collaborative strategy. Consequently, these companies apply for patents that improve their attractiveness as a co-operation or contract partner. Compared to using patents simply for the protection of the company's own technological know-how or even for blocking competitors, this strategy should not generate oppositions from other companies. Similarly, if these companies are important players in various cooperations, their partners are likely to solve possible disputes internally and not via raising oppositions. Based on these considerations, we derive the second hypothesis:

H2: The probability of an opposition against patents in a company's portfolio is

a) high, when the motive of protection is important in the company's patent strategy,

b) high, when the blocking motive is important in the company's patent strategy,

c) low, when the motive of exchange and collaboration is important in the company's patent strategy.

Generally, we argue that a motivation structure of patenting companies which tend to include more strategic elements shifts the characteristics of the portfolio towards a less valuable portfolio in the sense of citations. The incidence of opposition is also influenced by these motives.

\section{Description of Data}

Our analysis is based on the combination of survey information on companies' patenting motives with information on their patent portfolio. All German companies which had applied for a minimum number of three patents in 1999 - more than 1500 in total were contacted via a paper questionnaire in the year 2002 (Blind et al. 2003). The sur- 
vey achieved a high response rate of over 33\% and thus over 500 completed questionnaires were received. 5 The companies participating in the survey are responsible for more than $40 \%$ of all German applications at the European Patent Office for the year 1999. The survey thus covers a high share of very large, actively patenting companies. The sample comprises very large and very small companies with an average number of employees of 6,374 and a median of 517 employees. The companies which had answered the survey were then identified in the patent data of the European Patent Office. This was done via a string search comparing company name and address with the applicant information in the EPO data. The results of the search then underwent a thorough manual plausibility check. After removing observations with insufficient company information, we end up with a sample of 457 companies for which we have combined information on motives and EPO patents.

Now to a brief description of the construction of the motive structure we applied as explanatory variables. Originally, the patenting motives are taken from the company survey. Respondents were asked to rate the motives on a five-point scale from 1 for not important to 5 for very important. In order to collate the information about the motives we grouped them into the three categories (protection, blocking, exchanging). As we regarded the protection of innovation and market shares as the original protection motive, we decided through the correlation structure in Table 1 that those original variables should be transformed into one variable, the protection motive. It is calculated as the average assessment of all answers in this group. The offensive blocking motive is defined as preventing competitors from application of technological developments and was taken directly from assessments of the questionnaires. Defensive blocking of competitors is securing leeway to develop one's own technology without using the patents commercially. Again, this variable is taken directly from the questionnaire. The third block of motives - the exchange motives - is used as the average assessment of the motives income from licensing, use for cross-licensing, and cooperation.

Descriptive statistics relating to our dataset can be found in Table 2. We define two dependent variables to describe average characteristics of the patents contained in the portfolio. Our first characteristic is the average number of citations. ${ }^{6}$ Patents receive cita-

5 The large majority (more than 85\%) of the persons who filled in the questionnaire are involved in the strategic issues of patenting (CEO, patent department) and not in the purely technical aspects (R\&D manager, engineers). This supports the validity of the answers. Only $13 \%$ of the responses came from persons representing the $\mathrm{R} \& \mathrm{D}$ department.

6 We thank Dietmar Harhoff from the Ludwig-Maximilians-Universität in Munich for making the citation data available to us. A detailed description of the citation data can be found in Harhoff et al (2006). 
tions over a very long period of time, which makes older patents on average more heavily cited. To avoid an influence of the age of the patents in the portfolio, we only consider the citations that a patent receives in the first five years after the EPO published the search report for the patent. On average, a patent receives 0.73 citations including self-citations, i.e. citations by other patents of the same company. The phenomenon of opposition is captured by the share of patents that were opposed. This variable indicates that 4 percent of all patents are opposed.

Table 1: $\quad$ Correlation Structure of the Motives

\begin{tabular}{|c|c|c|c|c|c|c|c|c|c|}
\hline & $\begin{array}{l}\text { Imit. } \\
\text { prot. }\end{array}$ & $\begin{array}{c}\text { M. } \\
\text { share, } \\
\text { national }\end{array}$ & $\begin{array}{c}\text { M. } \\
\text { share, } \\
\text { Europe }\end{array}$ & $\begin{array}{c}\text { M. } \\
\text { share, } \\
\text { excl. } \\
\text { Eur. }\end{array}$ & $\begin{array}{c}\text { Off. } \\
\text { Block. }\end{array}$ & $\begin{array}{c}\text { Def. } \\
\text { block. }\end{array}$ & $\begin{array}{c}\text { Lic. } \\
\text { income }\end{array}$ & $\begin{array}{l}\text { Cross- } \\
\text { licensing }\end{array}$ & Coop. \\
\hline $\begin{array}{l}\text { Imitation pro- } \\
\text { tection }\end{array}$ & 1.00 & & & & & & & & \\
\hline $\begin{array}{l}\text { Market share, } \\
\text { national }\end{array}$ & $0.39 *$ & 1.00 & & & & & & & \\
\hline $\begin{array}{l}\text { Market share, } \\
\text { Europe }\end{array}$ & $0.35^{*}$ & $0.65 *$ & 1.00 & & & & & & \\
\hline $\begin{array}{l}\text { Market share, } \\
\text { excl. Europe }\end{array}$ & $0.21 *$ & $0.33^{*}$ & $0.69 *$ & 1.00 & & & & & \\
\hline $\begin{array}{l}\text { Offensive } \\
\text { blocking }\end{array}$ & $0.38 *$ & $0.26 *$ & $0.28 *$ & $0.26 *$ & 1.00 & & & & \\
\hline $\begin{array}{l}\text { Defensive } \\
\text { blocking }\end{array}$ & $0.23^{*}$ & $0.21 *$ & $0.25 *$ & $0.28 *$ & $0.24 *$ & 1.00 & & & \\
\hline $\begin{array}{l}\text { Income from } \\
\text { licencing }\end{array}$ & 0.04 & $0.12 *$ & $0.17^{*}$ & $0.23 *$ & 0.06 & 0.04 & 1.00 & & \\
\hline $\begin{array}{l}\text { Use for cross- } \\
\text { licencing }\end{array}$ & -0.02 & 0.01 & 0.08 & $0.18^{*}$ & 0.02 & $0.17 *$ & $0.47 *$ & 1.00 & \\
\hline Cooperation & 0.04 & $0.18^{*}$ & $0.20 *$ & $0.22 *$ & 0.06 & $0.20 *$ & $0.51 *$ & $0.50 *$ & 1.00 \\
\hline
\end{tabular}

Note: * indicates significance at the 5\%-level.

As an intermediate measure of patent value we use the companies' relevance assessment of the strategy of applying for patents in increasingly smaller steps. This was asked about using a five-point scale. We use a coding from 1 for companies that do not agree with the strategy to 5 for companies that agree. We interpret this as a strategy which leads to "thinner" patents with less scope than those with larger steps. Furthermore, patenting in smaller steps leads to less complex and hence less valuable patents within the portfolio. This smaller step strategy is the opposite of another strategy which has also been pursued in recent years, where the number of claims per patent grew and therefore a higher complexity of the patents can be assumed. This leads us to the assumption that 
an explicit application strategy of patenting in small steps is incorporated to reach certain goals in building large portfolios or creating fences around core innovations, but that this goes against the trend of creating highly complex patents. Companies evaluate this small step strategy on average with 2.96 on a 1 to 5 scale.

Table 2: $\quad$ Descriptive Statistics

\begin{tabular}{|lccccc|}
\hline & Mean & Median & s.d. & Min & Max \\
\hline Dependent Variables & & & & & \\
Citations & 0.73 & 0.65 & 0.56 & 0 & 4 \\
Share opposition & 0.04 & 0.00 & 0.08 & 0 & 1 \\
$\begin{array}{l}\text { Patenting in smaller } \\
\text { steps }\end{array}$ & 2.96 & 3 & 1.31 & 1 & 5 \\
Motives & & & & & \\
$\begin{array}{l}\text { Imitation protection } \\
\text { Defensive blocking }\end{array}$ & 3.95 & 4.0 & 0.82 & 1 & 5 \\
$\begin{array}{l}\text { Offensive blocking } \\
\text { Exchange }\end{array}$ & 3.85 & 4 & 0.96 & 1 & 5 \\
$\begin{array}{l}\text { Company Classifica- } \\
\text { tion }\end{array}$ & 2.46 & 2.33 & 1.07 & 1 & 5 \\
$\begin{array}{l}\text { Dummy defensive } \\
\text { blocking company }\end{array}$ & 0.40 & 0 & 0.49 & 0 & 5 \\
$\begin{array}{l}\text { Dummy offensive } \\
\text { blocking company }\end{array}$ & 0.07 & 0 & 0.26 & 0 & 1 \\
$\begin{array}{l}\text { Dummy exchange } \\
\text { company }\end{array}$ & 0.05 & 0 & 0.22 & 0 & 1 \\
Control Variables & & & & & \\
$\begin{array}{l}\text { Portfolio size (patent } \\
\text { applications with prior- }\end{array}$ & 114 & 15 & 631 & 1 & 9,534 \\
ity '91-'00) & & & & & \\
\hline
\end{tabular}

The average values of the motive clusters show rather pronounced differences in the importance of the motive clusters. It ranges from a high of 3.99 for defensive blocking to a low of 2.46 for the average of the exchange motives, whereas the blocking motives taken together reach an average assessment of 3.92. Offensive blocking is slightly less important than defensive blocking (3.85 compared to 3.99). We assume that in cases where the average evaluation of a certain motive is higher that there is a higher share of patents which are applied for according to this motive. 
In addition, we use dummy variables to classify the companies into four types according to their evaluation of the protection, defensive blocking, offensive blocking and exchange motive. Companies that give the protection motive a higher valuation than the remaining three motives constitute the basis category. The dummy for a defensive blocking company takes the value of one if this motive has the highest value and is zero otherwise. The dummies for offensive blocking and exchange company are defined analogously.

For the characteristics of the patent portfolios we consider patents that were applied for in the time period 1991-2000.7 On average the companies hold 114 patents, while the median is only 15 . This indicates a skewness of the distribution also found in other studies. We include dummies to control for the technology to which the majority of a company's patents belong. $48.9 \%$ of companies have a focus on mechanical technologies, $22.2 \%$ on electronics, $14.1 \%$ on chemicals, $5.5 \%$ on pharmaceuticals and $9.3 \%$ on other technologies.

A further description of the motive relevance among the patentees is given in Table 3. The upper panel shows how the motive evaluation is distributed over technology classes in which the companies mainly patent.

The variation among the technological fields is not considerable except in the case of chemicals. Here a higher valuation of all patenting motives reflects the higher reliance of this technology on patents. The lower panel of Table 3 displays that companies of different sizes vary in their evaluation of the motives. Especially very small and very large companies assign more importance to the exchange motive than medium-sized companies.

7 The results remain almost identical when we choose the time period 1996-2000. We assume that the characteristics of companies' patent portfolios are quite stable over time, which allows us to explain them with the company characteristics and motive assessments given in the year 2002. 
Table 3: $\quad$ Importance of Motives by Technological Area and Company Size, Means

\begin{tabular}{|lcccc|}
\hline & $\begin{array}{c}\text { Protection } \\
\text { Motive }\end{array}$ & $\begin{array}{c}\text { Blocking } \\
\text { Motive }\end{array}$ & $\begin{array}{c}\text { Exchange } \\
\text { Motive }\end{array}$ & $\begin{array}{c}\text { Number of } \\
\text { Observation }\end{array}$ \\
\hline Technological Area & & & & \\
\hline Pharmaceuticals & 3.94 & 3.90 & 2.52 & 29 \\
Chemicals & 4.23 & 4.15 & 3.18 & 66 \\
Electronics & 3.85 & 3.77 & 2.59 & 102 \\
Mechanical & 3.93 & 3.95 & 2.23 & 224 \\
Other & 3.85 & 3.81 & 2.22 & 36 \\
\hline Number of Employees & & & & 95 \\
\hline $1-100$ & 4.00 & 3.90 & 2.71 & 193 \\
$101-1000$ & 3.95 & 3.96 & 2.17 & 104 \\
$1001-5000$ & 3.88 & 3.83 & 2.44 & 65 \\
$>5000$ & 3.96 & 3.99 & 3.02 & 457 \\
\hline Total & 3.95 & 3.92 & 2.46 & \\
\hline
\end{tabular}

\section{Results and Interpretation}

In our empirical analysis we investigate how the average value of the patents in a company's portfolio and the incidence of opposition are related to the patenting motives of the company. In separate regressions, presented in Tables 4 and 6, we shed light on the direct relationship between several patenting motives and the patent portfolio characteristics. We apply a Tobit model in order to take into account the fact that more than 10 percent of the companies do not receive any citations. A similar pattern is observed for the opposition equation where the share of portfolios without any opposition is about 50 percent. The standard errors are estimated robustly in all equations.

Table 4 displays the regression results that are relevant for hypothesis 1 , which seeks to explain differences in the average citations of companies' patent portfolios. In columns (1) to (4) we use the average valuation of each motive as the explanatory variable in separate equations. If we use these average relevance assessments of the four clusters of motives (column (5)), we can confirm hypothesis 1a), namely that the more intensively companies use patents to achieve the protection objective, the higher is the average number of citations their patent portfolio receives (see also column (1)). However, we could not find significant support for hypotheses 1b) and 1c) using the average relevance assessment approach. The results of these separate regressions are shown in column (2) to (4). 
Table 4: $\quad$ Tobit Regressions Explaining Average Number of Citations (Marginal Effects)

\begin{tabular}{|c|c|c|c|c|c|c|}
\hline \multirow{2}{*}{$\begin{array}{l}\text { Dependent } \\
\text { Variable }\end{array}$} & \multicolumn{6}{|c|}{ Citations } \\
\hline & (1) & (2) & (3) & (4) & (5) & (6) \\
\hline Imitation protection & $\begin{array}{l}0.074 * * \\
(0.029)\end{array}$ & & & & $\begin{array}{c}0.081^{* * *} \\
(0.029)\end{array}$ & \\
\hline Defensive blocking & & $\begin{array}{c}0.009 \\
(0.026)\end{array}$ & & & $\begin{array}{l}-0.011 \\
(0.026)\end{array}$ & \\
\hline Offensive blocking & & & $\begin{array}{c}0.006 \\
(0.023)\end{array}$ & & $\begin{array}{l}-0.015 \\
(0.022)\end{array}$ & \\
\hline Exchange & & & & $\begin{array}{c}0.030 \\
(0.026)\end{array}$ & $\begin{array}{c}0.023 \\
(0.026)\end{array}$ & \\
\hline $\begin{array}{l}\text { Dummy defensive } \\
\text { blocking company }\end{array}$ & & & & & & $\begin{array}{l}-0.071 \\
(0.055)\end{array}$ \\
\hline $\begin{array}{l}\text { Dummy offensive } \\
\text { blocking company }\end{array}$ & & & & & & $\begin{array}{l}-0.104 * \\
(0.062)\end{array}$ \\
\hline $\begin{array}{l}\text { Dummy exchange } \\
\text { company }\end{array}$ & & & & & & $\begin{array}{c}-0.321 * * \\
(0.140)\end{array}$ \\
\hline Portfolio size & $\begin{array}{l}0.126 * * * \\
(0.016)\end{array}$ & $\begin{array}{c}0.130 * * * \\
(0.016)\end{array}$ & $\begin{array}{c}0.131 * * * \\
(0.016)\end{array}$ & $\begin{array}{c}0.125 * * * \\
(0.017)\end{array}$ & $\begin{array}{c}0.123 * * * \\
(0.017)\end{array}$ & $\begin{array}{c}0.133 * * * \\
(0.016)\end{array}$ \\
\hline No of observations & 457 & 457 & 457 & 457 & 457 & 457 \\
\hline $\begin{array}{l}\text { Log pseudo- } \\
\text { likelihood }\end{array}$ & -389 & -392 & -392 & -389 & -388 & -388 \\
\hline
\end{tabular}

Note: Marginal effects and their robust standard errors are reported. *, **, *** indicate significance at the $10 \%, 5 \%, 1 \%$ significance level. The regressions contain dummies for five technology classes and for four categories of company age.

In our first hypothesis, we state that companies that use patents to block competitors have patent portfolios of lower value. However, we differentiate further between offensive and defensive blocking strategies: we contend that the latter will lead to patents of higher value while the former will produce rather mediocre patents. The equation in column (5) integrates all average motive evaluations. Therefore we control for the absolute importance of patenting within the company which changes the results regarding the blocking motives, i.e. additional emphasis on using patents for blocking competitors now has a negative, but insignificant impact on the value of companies' portfolios.

An alternative approach is to construct dummy variable for specific types of companies. In column (6) we classify companies as having an overall tendency towards protecting, defensive blocking, offensive blocking, or exchanging. This dummy approach reveals 
conclusively that companies' patents receive fewer citations when it is an offensive blocking company or a company using patents in exchange relations with other companies. We can thus confirm hypothesis $1 b$ ) and c). The results of the Tobit regression in column (6) reveal emphatically that the patent portfolios of both companies using patents to block competitors offensively and those using them as bartering chips in the interactions with other companies receive significantly less citations on average for their patent portfolios compared to the companies employing patents to protect their own technological know-how.

In all three regression approaches, we find a significant positive influence of the portfolio size on the value indicator citations. The positive influence of the portfolio size on citations is a clear indication of economies of scale or even learning curves in the production of patents, which ultimately also leads to patents of higher value.

Summarising and interpreting the results of the regressions in order to explain the citations of companies' portfolios, we come to the following conclusion. The patent portfolios of companies that generally use patents to protect their technologies are of higher value than those of firms which try to block their competitors by strategic behaviour. This result exactly reflects our hypothesis one. In addition, we find a difference between the portfolio values of companies using patents for offensive and defensive purposes. This difference can be explained by the argument that defensive blocking leads to patents which are closely related to the already existing patent portfolio of the companies. Additionally, these patents already take future protection needs into account. Consequently, these patents benefit positively from the actual research activities and are very similar to patents applied to protect the current technological base. In contrast patents used for offensive blocking are of less technological value, since they are not able to benefit to the same extent from positive synergies with a firm's current research.

Furthermore, the average value of patents in the portfolios of companies using patents for their original purpose is also significantly higher than the average value of patents in portfolios of companies using patents to generate licensing revenues, as bartering chips in cross-licensing arrangements or in negotiations with other companies in cooperations. This result confirms our hypothesis 1c), but it is also an important indication that information inefficiencies still exist in markets for technology. As already argued above, portfolio size is an important indicator for those engaged in using patents in licensing and co-operation, which may also lead to the lower-value patent applications. However, our results indicate that there must still be a significant information problem in the market for technologies. In perfect markets, the competitive pressure on those trading patents should be so high that offering patents of lower value will be punished by significant damage to the reputation of the supplying company. Since we have to assume that collaborations in $R \& D$ tend to have more of a medium- and long-term per- 
spective rather than being short-term engagements, damage to the reputation of technology providers should be detrimental for their future perspectives in the licensing market and for their position in collaborations. However, this competitive pressure is not yet reflected in our regression results.

As an additional approach we look at whether the application behaviour of the patentees is influenced by the motives they cite as relevant (Table 5). In an ordered probit regression we can confirm that the complexity of patent applications measured in the higher share of patent applications in smaller steps, is significant smaller when the patentee evaluates the offensive blocking as very important. It is also evident that for cooperation and exchange, patenting in smaller steps accounts for a larger proportion of the patents in the portfolio. That indirectly supports the first hypotheses, i.e. that strategic goals of patenting such as blocking and exchange lead to less complex and hence less valuable patents, on average.

Regarding the second hypothesis focusing on the likelihood of oppositions, measured by the share of patents in a portfolio that are opposed, we apply the same regression models as presented in Table 4. Again, the relevance assessment of the protection motive has a significant impact on the probability of opposition which may point to a higher incidence of opposition for more valuable patents but also indicates that protection of technological know-how is a serious competitive strategy, which is likely to be answered by oppositions on the part of competitors (Table 6). Using the average evaluation of the other motives either solely or in the integrated equation does not reveal any significant relationship between the defensive blocking motivation and opposition against the companies' portfolios. The same holds for the exchange motive. However, we find a significant correlation between offensive blocking and the likelihood that a portfolio will face opposition (column (3)). The regression in column (5) considers this phenomenon as well. We can partly confirm hypothesis $2 b$ ), since especially aggressive offensive patenting provokes oppositions, whereas defensive blocking is not more likely to encourage oppositions from competitors than just protecting the actual technological base. Simple defensive blocking strategies may only lead to opposition, if the competitors behave rather aggressively, because both the incentives to oppose and the chances of successful opposition are lower than in the case of offensive patents, because the latter do not originate from the core of companies' technological bases. Using the integrated equation with all motives explaining the likelihood of opposition, the effect of the protection motive vanishes and becomes insignificant. 
Table 5: $\quad$ Ordered Probit Regressions Explaining Patent Applications in Smaller Steps

\begin{tabular}{|c|c|c|c|c|c|}
\hline \multirow{2}{*}{$\begin{array}{l}\text { Dependent } \\
\text { Variable }\end{array}$} & \multicolumn{5}{|c|}{ Smaller Steps } \\
\hline & (1) & (2) & (3) & (4) & (5) \\
\hline Imitation protection & $\begin{array}{c}0.094 \\
(0.054)\end{array}$ & & & & $\begin{array}{c}0.015 \\
(0.070)\end{array}$ \\
\hline Defensive blocking & & $\begin{array}{c}0.089 \\
(0.054)\end{array}$ & & & $\begin{array}{c}0.051 \\
(0.057)\end{array}$ \\
\hline Offensive blocking & & & $\begin{array}{c}0.113^{* *} \\
(0.050)\end{array}$ & & $\begin{array}{l}0.098^{*} \\
(0.053)\end{array}$ \\
\hline Exchange & & & & $\begin{array}{c}0.123 * * \\
(0.054)\end{array}$ & $\begin{array}{c}0.117 * * \\
(0.055)\end{array}$ \\
\hline Portfolio size & $\begin{array}{c}0.098 * * * \\
(0.034)\end{array}$ & $\begin{array}{c}0.099 * * * \\
(0.034)\end{array}$ & $\begin{array}{c}0.099 * * * \\
(0.034)\end{array}$ & $\begin{array}{c}0.081 * * \\
(0.035)\end{array}$ & $\begin{array}{c}0.072 * * \\
(0.055)\end{array}$ \\
\hline No of observations & 425 & 425 & 425 & 425 & 425 \\
\hline $\begin{array}{l}\text { Log pseudo- } \\
\text { likelihood }\end{array}$ & -666 & -665 & -664 & -664 & -661 \\
\hline
\end{tabular}

Note: Robust standard errors are reported. *, **, *** indicate that the coefficient is significantly different from zero at the $10 \%, 5 \%, 1 \%$ significance level. The regressions contain dummies for five technology classes and for four categories of company age.

In the model in column (6), we use the dummy approach in order to find out whether companies following a certain patent strategy have a higher likelihood of oppositions in their patent portfolios. We find no significantly higher share of oppositions among companies using patents for defensively blocking competitors compared to companies using patents in their originally intended sense. However, we can confirm that offensive blocking has a positive, but weakly significant effect. In model (6) we find strong support for our hypothesis 2c) that companies which favour the exchange strategy face less opposition than companies that use patents mainly to protect their inventions.

Companies employing patents as bartering chips in licensing arrangements or cooperations have a similar share of oppositions as those using patents for protection purposes. In the dummy model (column 6), we find even that this type of company has significantly lower shares of oppositions. This corresponds exactly to our argument that 
those companies are not interested in conflicts with potential collaboration partners due to possible damage to their overall reputation in the market for technology and that possible patent conflicts may be resolved informally without formal opposition processes.

Table 6: $\quad$ Tobit Regressions Explaining Share of Oppositions (Marginal Effects)

\begin{tabular}{|c|c|c|c|c|c|c|}
\hline \multirow{2}{*}{$\begin{array}{l}\text { Dependent } \\
\text { Variable }\end{array}$} & \multicolumn{6}{|c|}{ Share of Opposition } \\
\hline & (1) & (2) & (3) & (4) & (5) & (6) \\
\hline Imitation protection & $\begin{array}{c}0.007 * * \\
(0.004)\end{array}$ & & & & $\begin{array}{c}0.004 \\
(0.004)\end{array}$ & \\
\hline Defensive blocking & & $\begin{array}{c}0.001 \\
(0.026)\end{array}$ & & & $\begin{array}{l}-0.002 \\
(0.004)\end{array}$ & \\
\hline Offensive blocking & & & $\begin{array}{c}0.007 * * \\
(0.003)\end{array}$ & & $\begin{array}{l}0.006 * \\
(0.003)\end{array}$ & \\
\hline Exchange & & & & $\begin{array}{c}0.002 \\
(0.003)\end{array}$ & $\begin{array}{c}0.002 \\
(0.003)\end{array}$ & \\
\hline $\begin{array}{l}\text { Dummy defensive } \\
\text { blocking company }\end{array}$ & & & & & & $\begin{array}{l}-0.004 \\
(0.006)\end{array}$ \\
\hline $\begin{array}{l}\text { Dummy offensive } \\
\text { blocking company }\end{array}$ & & & & & & $\begin{array}{l}0.002 * \\
(0.009)\end{array}$ \\
\hline $\begin{array}{l}\text { Dummy exchange } \\
\text { company }\end{array}$ & & & & & & $\begin{array}{c}-0.022 * * \\
(0.007)\end{array}$ \\
\hline Citations & $\begin{array}{c}0.019 * * * \\
(0.005)\end{array}$ & $\begin{array}{c}0.020 * * * \\
(0.006)\end{array}$ & $\begin{array}{c}0.020 * * * \\
(0.006)\end{array}$ & $\begin{array}{c}0.020 * * * \\
(0.006)\end{array}$ & $\begin{array}{c}0.019 * * * \\
(0.005)\end{array}$ & $\begin{array}{c}0.019 * * * \\
(0.006)\end{array}$ \\
\hline Portfolio size & $\begin{array}{l}0.008 * * * \\
(0.002)\end{array}$ & $\begin{array}{c}0.008^{* * *} \\
(0.002)\end{array}$ & $\begin{array}{c}0.008^{* * *} \\
(0.016)\end{array}$ & $\begin{array}{c}0.008^{* * *} \\
(0.002)\end{array}$ & $\begin{array}{c}0.007^{* * *} \\
(0.002)\end{array}$ & $\begin{array}{c}0.008^{* * *} \\
(0.002)\end{array}$ \\
\hline No of observations & 457 & 457 & 457 & 457 & 457 & 457 \\
\hline $\begin{array}{l}\text { Log pseudo- } \\
\text { likelihood }\end{array}$ & -11.4 & -13.0 & -10.1 & -12.9 & -9.4 & -11.7 \\
\hline
\end{tabular}

Note: Marginal effects and their robust standard errors are reported. *, **, *** indicate significance at the $10 \%, 5 \%, 1 \%$ significance level. The regressions contain dummies for five technology classes and for four categories of company age.

We consider that the incidence of opposition is highly correlated with the value of the patented innovation but that the interpretation of this strategic instrument is complex. For this reason we included the citation measure as a control for the average value of patents in a portfolio. The coefficients of the motives then capture the impact on the strategic use of opposition as an indicator of dispute, not of value. In all six regression 
models both the citations and the portfolio size have a significant positive influence on the share of oppositions. More valuable patents clearly create stronger incentives for oppositions and larger players also face a positive scale effect in receiving oppositions. 8

Interpreting the regression results to explain the share of oppositions, we come to the following conclusions. Offensive blocking strategies provoke significantly more oppositions, whereas the impact of defensive blocking is no different than that of just using patents to protect the current technological portfolio. The rather weak support for our hypothesis, that blocking strategies have a positive influence on the share of oppositions, can explained by a further link we have proved in the regressions related to the citations. Here we argue and find the empirical evidence that the traditional use of patents to protect the technological base leads to patents of rather high value compared to the patents generated under a blocking strategy. The regressions explaining the shares of oppositions show a very strong explanatory power of the number of citations. Consequently, those companies utilising patents to protect their own technological know-how receive not only a higher number of citations, but also of oppositions. This effect reduces the difference to the pure opposition-provoking effect of companies that employ patents in their blocking strategies. This explains the rather low explanatory power of these variables, i.e. only offensive blocking is positively significantly correlated with the share of oppositions.

The companies using patents for exchange motives receive a smaller number of oppositions than those just using them for protecting objectives. Obviously, this company type intends to follow a protection strategy causing relatively little conflicts, since the negative reputation effect is much more severe and long-lasting in the whole market in which the company is active, compared to the gains of pursuing one specific patent claim against a possible competitor or collaboration partner.

\section{Conclusions}

This paper analyses for the first time how strategic motives for patenting are related to the characteristics of companies' patent portfolios. Using a data set of more than 400 companies we find - based on different regression approaches - that strategic patenting has an influence on the companies' patent portfolios.

$8 \quad$ See also Harhoff and Reitzig (2004). 
First, companies that use patents to protect their technological base and their markets receive a higher number of citations compared to those that use patents to block competitors or as bartering chips in collaborations with licensing relations. This finding confirms our first hypothesis. However, it should be noted that there is a difference between the patent portfolios of companies using patents for defensive blocking, i.e. securing their own future technological space, and applying patents to offensively block competitors. The latter receive a significantly lower number of citations.

Second, companies using patents to offensively block competitors receive - as postulated in our second hypothesis - a higher share of oppositions to their portfolios. There is no significant relationship between the defensive use of patents and the opposition indicator. A further hypothesis is also confirmed since companies using patents in exchange relations with licensees or licensors face a smaller share of opposition than those companies using patents merely for protection purposes.

These new insights make important contributions to the discussion on strategic patenting. Since we find considerable closeness between the traditional protection motive and the defensive blocking strategy, but significant differences between the latter and offensive blocking, we have to interpret defensive blocking as a kind of forward-oriented traditional protection strategy, which can therefore be subsumed into the traditional motive. Very different is offensive blocking of competitors by means of patents, which is clearly a case of the patent system being used for a purpose other than that for which it was originally intended. Although using patents as bartering chips in collaborations does not lead to patents of higher, but of lower quality, this motive has the positive sideeffect of avoiding conflicts in the opposition phase and looking for more informal and therefore more efficient conflict solution mechanisms. In summary, offensive blocking is the most critical and costly strategic patent motive from the perspective of the patenting authorities.

Based on these findings we can derive the following policy implications. First, the markets for technology are clearly quite efficient, since companies using patents as bartering chips possess patent portfolios with similar characteristics. It must also be noted that this type of company generally tries to follow a patenting strategy which does not cause severe conflicts with possible collaboration partners. This additional pressure to secure its reputation is a positive force for conflict resolution. Second, the phenomenon of frequent oppositions and rather limited citations in a company's patent portfolio is an incidence that the company is implementing an offensive blocking strategy and thus misusing the patent system. This is a potential information source, which could be used in investigations of anti-competitive behaviour in specific markets or by single companies. In summary, this investigation has confirmed the validity and the usability of patent portfolio characteristics not only for innovation management, but also policy issues. 


\section{References}

Arundel, A. (2001): The relative effectiveness of patents and secrecy for appropriation. In: Research Policy, 30, pp. 611-624.

Arundel, A.; Patel, P. (2003): Strategic patenting, Background report for the Trend Chart Policy Benchmarking Workshop "New Trends in IPR Policy".

Arundel, A.; van de Paal, G.; Soete, L. (1995): Innovation strategies of Europe's largest industrial firms. Results of the PACE survey for information sources, public research, protection of innovations and government programmes. Final report, MERIT, PACE report; Brussels.

Blind, K.; Edler, J.; Frietsch, R.; Schmoch, U. (2006): Motives to patent: empirical evidence from Germany. In: Research Policy, 35, pp. 655-672.

Blind, K.; Edler, J.; Frietsch, R.; Schmoch, U. (2004): The Patent Upsurge in Germany: The Outcome of a Multi-Motive Game Induced by Large Companies, working paper presented at the 8th Schumpeter Conference in Milano, Karlsruhe: Fraunhofer Institute Systems and Innovation Research (ISI).

Blind, K.; Edler, J.; Frietsch, R.; Schmoch, U. (2003): Patente versus Erfindungen: Schwerpunktstudie zur "technologischen Leistungsfähigkeit Deutschlands", Fraunhofer-Institut für Systemtechnik und Innovationsforschung (Karlsruhe) (ed.), Karlsruhe.

Blind, K.; Edler, J.; Friedewald, M. (2005): Software Patents: Empirical Evidence and Policy Implications, Cheltenham: Edward Elgar.

Cohen, W.; Nelson, R.R.; Walsh, J. (2000): Protecting Their Intellectual Assets: Appropriability Conditions and Why U.S. Manufacturing Firms Patent (Or Not), Working Paper 7552, Cambridge, MA: National Bureau of Economic Research.

Cohen, W.M.; Goto, A.; Nagata, A.; Nelson, R.R.; Walsh, J.P. (2002): R\&D spillovers, patents and the incentives to innovate in Japan and the United States. In: Research Policy, 31, pp. 1349-1367.

Graham, S.; Hall, B.H.; Harhoff, D.; Mowery, D.C. (2003): Post-issue Patent 'Quality Control:' A Comparative Study of U.S. Patent Reexaminations and European Patent Oppositiones. In: The Patent System in the Knowledge-Based Economy. Cohen, W.; Merrill, S. (eds.). Washington: National Academies Press.

Granstrand, O. (1999): The Economics and Management of Intellectual Property: Towards Intellectual Capitalism, Cheltenham: Edward Elgar.

Hall, B.H.; Ziedonis, R.M. (2001): The patent paradox revisited: an empirical study of patenting in the U.S. semiconductor industry, 1979 - 1995. In: The Rand Journal of Economics, 32 (1), pp. 101-128. 
Harhoff, D.; Reitzig, M. (2004): Determinants of opposition against EPO patent grants The case of biotechnology and pharmaceuticals. In: International Journal of Industrial Organization, 22 (4), pp. 443-480.

Harhoff, D.; Scherer, F.M.; Vopel, K. (2003): Citations, Family Size, Opposition and the Value of Patent Rights. In: Research Policy, 33, pp. 1343-1363.

Harhoff, D.; Hoisl, K.; Webb, C. (2006): European patent citations - How to count and how to interpret them?, Munich: University of Munich.

Hussinger, K. (2006): Is Silence Golden? Patents versus Secrecy at the Firm Level. In: Economics of Innovation and New Technology, 15 (8), pp. 735-752.

Jaffe, A.B. (1999): The U.S. Patent System in Transition: Policy Innovation and the Innovation Process, NBER working paper series; 7280, Cambridge, Massachusetts: National Bureau of Economic Research.

Jaffe, A.B.; Lerner, J. (2004): Innovation and Its Discontents: How Our Broken Patent System is Endangering Innovation and Progress, and What to Do About It, Princeton, N. J.: Princeton University Press.

Janz, N.; Licht, G.; Doherr, Th. (2001): Innovation Activities and European Patenting for German Firms - Proceedings of the Annual Conference of the European Association of Research of Industrial Economics (EARIE), Dublin: EARIE.

Kortum, S.; Lerner, J. (1999): What is behind the recent surge in patenting? In: Research Policy, 28, pp. 1-22.

Lanjouw, J.O.; Schankerman, M. (2004): Patent Quality and Research Productivity: Measuring Innovation with Multiple Indicators. In: Economic Journal, 114, pp. 441-465.

Noel, M.; Schankerman, M. (2006): Strategic Patenting and Software Innovation, CEPR Discussion Paper 5701.

Peeters, C.; van Pottelsberghe de la Potterie, B. (2006): Innovation strategy and the patenting behavior of firms. In: Journal of Evolutionary Economics, 16, pp. 109135.

Putnam, J. (1996): The Value of International Patent Rights - PhD thesis, New Haven: Yale University.

Schalk, H.J.; Täger, U.C.; Brander, S. (eds.) (1999): Wissensverbreitung und Diffusionsdynamik im Spannungsfeld zwischen innovierenden und imitierenden Unternehmen, München: Ifo-Institut für Wirtschaftsforschung.

Shapiro, C. (2003): Antitrust limits to patent settlements. In: Rand Journal of Economics, 34 (2), pp. 391-411. 
Sine, W.D.; Shane, S.; Di Gregorio, D. (2003): The Halo effect and technology licensing: The influence of institutional prestige on the licensing of university inventions. In: Management Science, 49 (4), pp. 478-496.

Somaya, D. (2003): Strategic Determinants of Decisions not to Settle Patent Litigation. In: Strategic Management Journal, 24, pp. 17-38.

Thumm, N. (2003): Research and Patenting in Biotechnology: A Survey in Switzerland, Bern: Swiss Federal Institute of Intellectual Property.

Traijtenberg, M. (1990): A Penny for your Quotes. Patent Citations and the Value of Innovation. In: Rand Journal of Economics, 21 (1), pp. 172-187.

Varian, H.R.; Farrell, J.; Shapiro, C. (2004): The economics of information technology: An introduction, Cambridge: Cambridge University Press. 